\title{
Industrial strategy: do the government's proposals match up to the task?
}

\author{
Steve Fothergill* \\ CRESR, Sheffield Hallam University
}

\begin{abstract}
This article assesses the UK government's proposals on industrial strategy, published in a Green Paper in January 2017. The need for an industrial strategy is rooted in fundamental imbalances in the UK economy. The proposals in the Green Paper, however, are modest. There is substantial new money for R\&D and on issues such as procurement and skills the government makes the right commitments, but the Green Paper fails to address a number of major issues that are key to an industrial revival.
\end{abstract}

Keywords: Industrial strategy, UK, Manufacturing, Green Paper.

\section{Background}

It happened rather quickly and unexpectedly. In a speech in Birmingham on 11 July 2016 as part of her bid for the Conservative Party leadership, Theresa May MP called for an industrial strategy for the UK. This was an unusual message from a leading Conservative politician. Two days later Theresa May was the new Prime Minister (though not because of her stance on industrial policy). By the following day, the Department for Business had acquired a new name - the Department for Business, Energy and Industrial Strategy.

The sudden prominence of industrial strategy is a departure from the conventional wisdom that previously pervaded government. The outgoing Business Secretary Sajid Javid MP, for example, was known for his view that the role of government is to get out of the way and let business and market forces drive the economy. Non-interventionist, neo-liberal economics seemed to have established hegemony over thinking on industry and industrial policy.

But how much has really changed and, if the UK government has genuinely set a new course on industrial policy, are its proposals up to the task? This article reviews the government's emerging industrial strategy, set out in a Green Paper published in January 2017 (HM Government, 2017). It does so in three stages. First, it outlines the scale of the challenge and explains why a revival in the performance of UK industry is so desperately needed. Second, it summarises the government's proposals. Third, it examines the strengths and weakness of the proposals, including the substantial omissions from the present published strategy. Britain's impending departure from the European Union provides a key backdrop of course. 


\section{The need for an industrial strategy}

The British economy is fundamentally imbalanced and the country's prosperity is deeply precarious as a result. In the wake of the financial crisis in 2008 and during the subsequent recession there was much talk about the need to rebalance the economy away from financial services towards production, investment and exports. A revival in industry was also seen as the way to reduce the economy's dependence on London and to spread growth more evenly around the UK. The then Chancellor, George Osborne MP, closed his 2011 Budget speech by calling for "the march of the makers."

This hasn't happened. The British economy remains at least as imbalanced now, if not more so, than before the financial crisis and manufacturing output has still not recovered to its pre-recession level (Office for National Statistics, 2017). The consequence is that the UK economy continues to display alarming features:

- An extraordinary level of household debt - among the very highest in the world.

- A public sector budget deficit that remains large despite the most draconian austerity measures in modern times.

- A trade deficit with the rest of the world at near record levels.

These features of the contemporary UK economy are deeply interrelated. As any economist will explain, everyone's expenditure is someone else's income so if the UK public and private sectors are together spending more than their income the result is a trade deficit with the rest of the world. This then has to be financed by financial transfers from abroad. In essence, the UK is living beyond its means. Consumption and living standards are being sustained not by incomes earned by trading with each other and the rest of the world but by ever-rising debt and the sale of UK assets companies, property, government bonds - to foreign investors.

If investors lose patience or faith in the UK the consequences are dire: a collapse in sterling, higher prices, lower living standards, falling consumer spending, recession and still more public debt and even more austerity. There was at least a taste of this in the sharp fall in the value of sterling in the wake of the EU referendum result. A lower exchange rate helps exports but the resulting higher inflation is now feeding though and, via its effect on real wages, will act as a drag on growth in the next few years (HM Treasury, 2017).

The reason why the UK economy has become so imbalanced and precarious is that successive governments have neglected its industrial base. It used to be said that Britain was the workshop of the world but that was many decades ago. In the $21^{\text {st }}$ century Britain's claim to fame is more likely to be as a financial capital and maybe as a cultural capital too. That Britain has proved so good at selling services to the rest of the world is immensely welcome. There is also, no doubt, more that could still be done to promote the export of British services around the world, but the successes of the service sector should not obscure the failures in manufacturing. Nor should we be lulled into thinking that the successes of one offset the failures of the other.

- Around half the value of all UK exports still comes from manufacturing.

- Manufacturing, with just 10 per cent of the UK workforce, therefore sells as much to the rest of the world as the other 90 per cent put together. 
- But it is trade in goods, not services, in which the UK deficit is so staggeringly large.

- And after years of neglect, British manufacturing is effectively 'hollowed out' whole sectors have simply disappeared.

It is wrong to think of industry as something from the past. This may be the reality in too many former industrial towns, but industry remains central to every other major advanced economy. It is also wrong to think that high-wage economies like the UK cannot retain a large manufacturing sector in the face of competition from China and other developing countries. The experience of Germany, where labour costs are generally even higher than in the UK, robustly refutes this claim. In Germany, the share of manufacturing in GDP is more than double the level in the UK - and Germany has a huge trade surplus.

Unless the alarming long-term trends in industrial production are addressed the British economy faces a bleak future. At a time when productivity growth in the UK is flagging, a revival in industry offers the prospect of high value-added jobs. A revival in industrial production also offers the prospects of higher exports to begin to bring the economy back into balance, and more jobs in the regions away from London and the South East.

\section{The government's proposals}

Strictly speaking, a Green Paper is not a final statement of UK government policy. It is an interim document setting out ideas that may, or may not, be confirmed in a subsequent White Paper. The consultation on the Green Paper on industrial strategy, for example, ran for three months. But it would be very surprising, given the way that governments operate, for the final proposals to look immensely different.

The UK government has organised its proposals on industrial strategy into what it calls ' 10 pillars.' For the sake of clarity, these are worth listing alongside the accompanying explanation in the government's own words (HM Government, 2017: 11):

\section{Investing in science, research and innovation}

"We must become a more innovative economy and do more to commercialise our world leading science base to drive growth across the UK."

\section{Developing skills}

"We must help people and businesses to thrive by: ensuring everyone has the basic skills needed in a modern economy; building a new system of technical education to benefit the half of young people who do not go to university; boosting STEM (science, technology, engineering and maths) skills, digital skills and numeracy; and by raising skill levels in lagging areas."

\section{Upgrading infrastructure}

"We must upgrade our standards of performance on digital, energy, transport, water and flood defence infrastructure, and better align central government infrastructure investment with local growth priorities." 
p. 108. Industrial strategy: do the government's proposals match up to the task?

\section{Supporting businesses to start and grow}

"We must ensure that businesses across the UK can access the finance and management skills they need to grow; and we must create the right conditions for companies to invest for the long-term."

\section{Improving procurement}

"We must use strategic government procurement to drive innovation and enable the development of UK supply chains."

\section{Encouraging trade and inward investment}

“Government policy can help boost productivity and growth across our economy, including by increasing competition and helping to bring new ways of doing things to the UK."

\section{Delivering affordable energy and clean growth}

"We need to keep costs down for businesses, and secure the economic benefits of the transition to a low-carbon economy."

\section{Cultivating world-leading sectors}

"We must build on our areas of competitive advantage, and help new sectors to flourish, in many cases challenging existing institutions and incumbents."

\section{Driving growth across the whole country}

"We will create a framework to build on the particular strengths of different places and address factors that hold places back - whether it is investing in key infrastructure projects to encourage growth, increasing skill levels, or backing local innovation strategies."

\section{Creating the right institutions to bring together sectors and places}

"We will consider the best structures to support people, industries and places. In some places and sectors there may be missing institutions which we could create, or existing ones we could strengthen, be they local civic or educational institutions, trade associations or financial networks."

These all seem eminently reasonable proposals, or more accurately aspirations. There is even a prominent mention of 'lagging areas' and reference to the need to make sure the whole of the UK benefits from the new strategy, which should please those in poorer regions and nations. But the ' 10 pillars' also beg many questions. Aren't these the things that government was doing anyway, in the normal course of business? What exactly is new? Where are the new policy commitments? Where are the new budget lines?

\section{An assessment}

The truth is that there isn't a great deal of additional public money behind the industrial strategy, and the money that does appear to be new was mostly announced in the Autumn Statement a few months earlier (HM Treasury, 2016).

By far the most significant new money is the additional funding for research and development, worth an extra £2bn a year by 2020-21, or an increase of around 20 per cent in total government R\&D spending. The government is still consulting on how further tranches of this money should be spent. There are worries, however, about exactly which parts of the country might benefit. As the Green Paper itself points out, at 
present 46 per cent of Research Council and Higher Education Funding Council for England (HEFCE) funding is spent in Oxford, Cambridge and London (HM Government, 2017: 29). The risk is that we could end up with more labs working in glamourous hightech sectors in these places but not much impact on the more humdrum industries that make up the bulk of manufacturing across the rest of the country.

The details of the government's Industrial Strategy Challenge Fund, which will be used to allocate an initial $£ 1$ bn of the new money for R\&D, underline the concern that the focus is unreasonably narrow. In an announcement in April 2017 (Department for Business, Energy and Industrial Strategy, 2017), the government identified just six sectors as eligible for this funding - healthcare and medicine, robotics and artificial intelligence, batteries, self-driving vehicles, materials for the future and satellites \& space technology. Whatever their longer-term prospects, these sectors account for a tiny sliver of the present-day economy.

Beyond R\&D it is harder to find new money in the Green Paper. On skills there is a new commitment to spend $£ 170 \mathrm{~m}$ of capital funding on the creation of new Institutes for Technology. This money appears to come from within existing education budgets. It is questionable, however, whether such a modest sum can deliver all the Institutes that are needed. If they are intended to meet the needs of young people living at home or on day release from employers, it seems unlikely that the funding will stretch to one for every local labour market.

Nevertheless, the new industrial strategy should not be judged on funding alone. Apart from money, what is important is that policies and practices across a range of departments are aligned with promoting an industrial revival, and on that front the government does seem to be making at least some of the right noises.

The commitment to technical education, for example, is clearly what is needed. The UK has a dreadful record on technical skills, especially in comparison to Germany where there has long been a system combining high-level formal education with on-thejob training in industry. The plans trailed in the Green Paper and confirmed in the 2017 Budget to simplify the vast array of technical qualifications are probably a good move. The Apprenticeship Levy, introduced for the first time in April 2017, may not however be as good as it first seemed because it is unclear that all the additional revenue $£ 2.7$ bn in 2017-18 (HM Treasury, 2015) - is feeding through to higher spending on training and skills development.

Likewise, the emphasis on public procurement as a development tool is welcome even if it only re-affirms what the UK government has been saying since 2010. In earlier years, government missed a trick by failing to use procurement to foster UK supply chains and help smaller firms in particular. In the wake of Brexit it may well prove possible to do more, though the extent to which EU competition rules will continue to apply remains an unknown at this stage.

On infrastructure there seems to be a disjuncture between aspirations and actions. HS2, Hinkley Point $\mathrm{C}$ and the third runway at Heathrow all get a mention in the Secretary of State's introduction to the Green Paper (HM Government, 2017: 7), but it is questionable whether these particular mega-projects will thrill most manufacturers in the regions unless they expect to win construction and equipment supply contracts. More generally, it remains unclear how far the infrastructure announcements in the Green Paper go beyond what the government has already promised, or indeed what was already in the pipeline. The money earmarked for housing in the 2016 Autumn Statement is highlighted, but this seems a very indirect way of supporting industry in the regions, especially if housing investment is focussed on London and the South East. 
The main criticism of the Green Paper, however, is that it fails to say anything of significance on several key issues.

First, government has a responsibility to get the macroeconomic context right. Industry needs a competitive exchange rate, low interest rates to foster investment and a measured approach to deficit reduction to maintain demand in the economy. The combination of a high exchange rate and high interest rates wrecked so much of British industry in the 1980s and 90s, and spending cuts after 2010 slowed recovery from recession. Sadly, there is nothing in the Green Paper that offers reassurance.

Second, while the commitment to free trade is heartening, bearing in mind the need to maintain access to the single market following Brexit, there is nothing in the Green Paper about the need to ensure that competition is always fair. Indeed, the focus is exclusively on promoting exports. UK manufacturers should be alarmed. The UK steel industry, for example, faces an existential threat from vast quantities of surplus Chinese steel being dumped at below cost. More generally, UK manufacturers should not be allowed to suffer as a result of unfair competition from countries that fail to respect workers' rights, health or safety or environmental obligations. Outside the EU, the UK will need to develop its own effective trade defence instruments to head off unfair competition of this kind, but there is no evidence in the Green Paper that the government has given this any thought.

Third, the Green Paper barely addresses the need to provide long-term finance for industry. The proposals are weak on this front and do not extend much beyond further reviews. They also ignore the existing EU-funded support at risk as a result of Brexit. Whilst the activities of the British Business Bank and a number of regional funds are welcome, they only address the needs of smaller firms. The big banks have a dreadful record in providing long-term finance for industry. They should not be let off the hook.

Fourth, the proposals fail to exploit the scope to provide aid to industry. This is an important blind spot. Even within present-day EU State Aid rules there is already scope for a much more adventurous approach to business support, and following Brexit there may well be further opportunities. Indeed, the cross-party Business, Energy and Industrial Strategy Committee (2017) noted that the UK spends substantially less per head on state aid than several of its European competitors, including France and Germany. The government, however, remains hesitant to exploit the potential to provide such assistance. In particular, since the Regional Growth Fund was discontinued in 2015 the UK government has failed to offer investment aid to businesses in England's less prosperous regions.

Fifth, the proposals fail to offer help to energy-intensive industries. Industries such as steel, glass, ceramics and heavy chemicals are badly hit by 'green' energy charges and as a result their international competitiveness is undermined. There is a risk that jobs (and the carbon emissions that go with them) will simply be exported. The Green Paper's commitment to keeping energy costs down is welcome, though it is hard to see how new nuclear, in particular, can deliver this given its exorbitant costs and the deal the government has struck for consumers to carry the burden. Although energyintensive industries have been exempted from some green charges, there is nothing new in the Green Paper for them. In particular, there is nothing to offset the higher electricity prices arising from the UK's 'carbon tax'. 


\section{Concluding remarks}

In all, the UK government's new industrial strategy is a disappointment. The political willingness to do something seems to be there, but the delivery looks weak.

Indeed, to a seasoned observer the Green Paper bears the hallmarks of a paper assembled by civil servants to keep their ministers happy but not really change very much. The Green Paper has certainly been a cross-government effort - it is not difficult to spot the parts that have their origin in the Departments for Business, Education, Communities and Local Government, Cabinet Office and even the Ministry of Defence. But in each case the response of civil servants has been to list all the things relevant to industry that their department is already doing, and then add a number of new initiatives that were already in the pipeline.

The Green Paper, for all its fine aspirations, therefore ends up lacking vision. It is hardly surprising therefore that as a result it has not triggered a great deal of controversy. The media sensed quite correctly that it did not seem like a game-changer. The Business, Energy and Industrial Strategy Committee got it right when it concluded that "while the government's rhetoric marks a step change, and the creation of a new Department for Business, Energy and Industrial Strategy has significantly raised expectations, the government's approach appears to be evolutionary" (BEIS Select Committee, 2017: 3).

It could have been so different. Above all, it would have been helpful if ministers had said that they will hold the line here, and that they will not allow Britain to abandon any more sectors of manufacturing production. This would have represented a clean break with the past. They could have said that what is left of British industry is actually very good - it has had to be, in order to survive this long - and that it provides the base for moving forward. Instead, the new industrial strategy looks much more like business as usual.

* Correspondence address: Professor, Steve Fothergill, CRESR, Sheffield Hallam University, Unit 10, Science Park, Howard Street, Sheffield, S1 1WB. Email: natsec@ccc-alliance.org.uk

\section{References}

Business, Energy and Industrial Strategy Committee (2017) Industrial Strategy: first review, Second report of session 2016-17. London: House of Commons.

Department for Business, Energy and Industrial Strategy (2017) Business Secretary announces Industrial Strategy Challenge Fund investments, press release 21 April.

HM Government (2017) Building Our Industrial Strategy, Green Paper. London: HM Government.

HM Treasury (2015) Spending Review and Autumn Statement. London: HM Treasury.

HM Treasury (2016) Autumn Statement. London: HM Treasury.

HM Treasury (2017) Budget 2017. London: HM Treasury.

Office for National Statistics (2017) UK Index of Production, February 2017. London: ONS. 